REVISTA DE LITERATURA E CULTURA RUSSA

\title{
Dos corpos aos crematórios: ideologia e ironia em Bobók
}

\section{From bodies to crematoria: ideology and irony in Bobok}

Autora: Elizabete Barros de Sousa Lima Universidade Federal do Norte do Tocantins, Tocantins, Brasil Autor: Otávio Augusto Buzar Perroni Universidade de Brasília, Brasília, Distrito Federal, Brasil Edição: RUS Vol. 12. No 20 


\section{Dos corpos aos crematórios: ideologia e ironia em Bobók}

\section{Elizabete Barros de Sousa Lima* Otávio Augusto Buzar Perroni*}

Resumo: Bobók é um dos contos mais representativas de Dostoiévski. A obra critica as ideologias dominantes, baseando-se no humor para destronar as vozes de autoridade. Assim, o artigo visa discorrer acerca da importância da literatura de Dostoiévski para a formação crítica social por meio do riso, versando sobre a notabilidade do elemento risível para a atenuação das desigualdades e, assim, contribui para reafirmar a necessidade da literatura do riso para a reflexão social.

\begin{abstract}
Bobok is one of the most striking tale by Dostoiévski. This tite is a criticizes to the domination ideology, based on the laughable to take the power of those authorities. Consequently, the article intentes to dissertate about the social impact of the Dostoiévski's literature through humor, writing about the notable laughable in the social inequality sistem. Reaffirming the necessity of humor to social thinking.
\end{abstract}

Palavras-chave: Bobók, Ideologia; Ironia; Crítica social Keywords: Bobok; Ideology; Irony; Social criticism 
Acho que o mais inteligente é quem ao menos uma vez por mês chama a si mesmo de imbecil - capacidade de que hoje não se ouve falar! Antes ao menos uma vez por ano o imbecil sabia sobre si mesmo que era imbecil, mas hoje, nem isso. $E$ confundiram tanto a coisa que a gente não distingue o imbecil do inteligente. Isso eles fizeram de propósito.

Bobók

* Professora de Literatura da Universidade Federal do Norte do Tocantins (UFNT). Doutora em literatura comparada. Participante dos grupos de Pesquisa: Literatura e cultura; Textualidades contemporâneas. https://orcid. org/0000-0002-2899-6423; elizabete.bs001@gmail.com

\footnotetext{
** Mestrando em Literatura (PósLit, Universidade de Brasília). Membro do grupo de Pesquisa: Literatura e Cultura (PósLit, Universidade de Brasília). Especialista em Direito Processual Civil (Universidade do Sul de Santa Catarina e Instituto Brasileiro de Direito Processual) Procurador Federal; https://orcid.org/00000001-8216-2625; otavio.perroni@ gmail.com
}

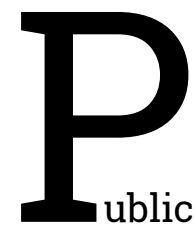

ublicado originalmente em 1873 no jornal O Cidadão, Bobók, obra-prima de Dostoiévski, narra extenso diálogo no mundo dos mortos. O conto do escritor, que de acordo com Paulo Bezerra foi uma resposta às críticas ao romance Os demônios, publicado anteriormente e reconhecido como panfletário, tece julgamentos sobre as aparências sociais formalizadas a partir de classes. Essa discussão, em que o universo da obra procura aproximar as pessoas, alegoriza uma sociedade monológica e autoritária, posto que o distanciamento entre os indivíduos ocorre simplesmente pelo capital que cada um possui, afastando-se da ética.

O conto Bobók, escrito em 1873, surgiu como resposta à crítica da época dirigida contra Dostoiévski após a publicação do livro Os demônios. Os críticos viram o tratamento dado pelo autor à loucura como algo banal, que criou um romance com um cenário próximo do que seria um hospital cheio de pacientes excêntricos, trazendo uma série de equívocos que não passavam de "delírios do próprio autor". Assim, a crítica acabou tentando desqualificar o próprio Dostoiévski, chamando-o de louco e anunciando ser o fim do escritor consagrado pelo seu romance anterior, Gente pobre. ${ }^{1}$

1Dostoiévski, Fiódor. 2012, p. 43. 
Os argumentos críticos levantados acerca da obra do autor desconsideram a capacidade crítica do objeto romanesco. Mas é importante assinalar, reconhecendo essas falas que afastam obra, tempo e cultura, que o intelectual tem um papel social em sua comunidade, ele carrega no discurso a possibilidade de dar corpo a uma ideia, articular pontos de vista e, com isso, propagar mudanças. Assim, é propagador de mudanças, pois recolhe fatos da vida, coloca-os em papel e apresenta ao seu leitor. Esse destinatário da palavra pega esses fragmentos da vida e compara-os ao seu cotidiano e às mininarrativas que o circulam. Com isso é capaz de constatar as semelhanças inerentes à narrativa e à vida. Dessa forma, consegue, a partir dessa visão distanciada, reconhecer os problemas presos à sua comunidade, o que pode modificar sua visão de mundo, contrastando narrativas variadas, e avaliando as que mais se aproximam de sua visão ideológica. Era a partir dessa vontade de representar o mundo com seus defeitos, desvios e vícios que Dostoiévski construía as suas narrativas, operando diretamente nas fragilidades de seu país e oferecendo ao leitor os rastros de uma sociedade doente, padecedora de muitas mazelas, que não se restringiam a uma camada específica, estavam centralizadas em todos os espaços.

O clima psicológico desencadeado por essa crítica hostil ao romance Os demônios reflete-se diretamente na estrutura de Bobók, que é marcada por uma profunda tensão traduzida no comportamento do protagonista e nos vaivéns de sua linguagem. Observando a maioria das resenhas e críticas a Os demônios, nota-se que nelas predomina a ideia de desequilíbrio, delírio e loucura, em suma, toda uma estratégia da crítica cujo fim é desqualificar obra e autor, irritá-lo e tirá-lo do prumo, levá-lo a cometer "desatinos". O narrador aceita o desafio e mergulha nesse clima, vai desenvolvendo seu movimento pendular de sentimentos contraditórios, onde aparecem elementos dialógicos como evasivas, cisões, intermitências acentuais, reticências etc., numa tensão diabólica entre aceitação e rejeição da palavra do outro. Mas isto é uma estratégia da narrativa para preparar a contraposição do autor, que está por trás do narrador. ${ }^{2}$

2 Dostoiévski, Fiódor. Bobók. Editora 34 Ebook. Edição do Kindle. 
Em Bobók, por sua vez, Dostoiévski utiliza a ironia como espaço de crítica. Esta figura de linguagem não aparece por acaso, ela vem para falar de uma figura pública, de uma sociedade, de um país, portanto, sempre tem um alvo. Logo, podemos destacar que não é criada por acaso, mas em função da enunciação de algo que se apropria do poder como forma de exclusão, de minorar os outros. Fruto de espaço social e literário conturbado, o escritor russo percebia, em sua sociedade, a supressão do discurso alheio, a determinação do homem, o monologismo cultural. Reconhecendo essas fraturas, constrói obras que procuram dar voz aos silenciados, em um ato de aproximação dos indivíduos, quebrando as hierarquias sociais por meio do rebaixamento de suas personagens.

Assim, Hutcheon (2000, p. 36) destaca a importância do discurso para a formação dos enunciados irônicos.

Porque a ironia, como definida neste estudo, acontece em alguma coisa chamada "discurso", suas dimensões semântica e sintática não podem ser consideradas separadamente dos aspectos social, histórico e cultural de seus contextos de emprego e atribuição. Questões de autoridade e poder estão codificadas na noção de "discurso" hoje de maneira muito semelhante de como, tempos atrás, elas eram codificadas na palavra retórica. ${ }^{3}$

Frente ao exposto pela autora, é necessário salientar que o livro literário tem um grande poder sobre os recursos de ironia, visto que sua linguagem metafórica possibilita a criação de ambientes fictícios que possibilitam o jogo e a farsa da linguagem. O texto literário possui o poder de dizer sobre o outro, e essa palavra comunica, fala sobre identidades, carregando, assim, a possibilidade de reafirmar ou desconstruir discursos prontos. Mesmo que às vezes ela seja utilizada para reforçar as opressões, seu caráter polifônico possibilita que enunciatários diferenciados estejam propensos a entendê-la de formas diferentes. Isso ocorre devido aos contextos discursivos, que são essenciais para o entendimento do significado irônico. Com isso, a ironia se concretiza no ato singular de um falante e um ouvinte, na relação estabelecida entre o ironista e seu

3 BURKE, 1969b: 50. 
contexto histórico em constante interação com os elementos linguísticos que alimentam a situação discursiva, como explana Hutcheon.

Ademais, Lyra (1979) aponta que toda literatura é ideológica, pois comporta as ideologias de quem a escreve. Se ela se mostra esteticamente envolvida com questões sociais, coloca-se na posição oponente, dissonante ao sistema ao qual está inserida. Quando não há resquícios de contestação, também guarda em si uma ideologia, que é aquela de acordo com o pensamento dominante, representante da doxa. Mas não percebemos a arte como elemento neutro, pois é parte de um sistema, ou o critica ou o responde e transmite ao outro os conhecimentos como saber universal. É assim que enxergamos Bobók, um conto que equaciona, em pequeno espaço, temáticas sociais relevantes, que se direciona à sociedade de seu escritor, respondendo esteticamente às acusações que o autor russo recebeu em momentos de publicação do romance Os demônios. Tais frestas de pensamento podem ser reconhecidas no seguinte trecho:

Diga pelo menos de forma indireta, para isso você tem estilo. Não, de forma indireta ele já não quer. Hoje o humor e o bom estilo estão desaparecendo e se aceitam insultos em vez de gracejos. Não me ofendo: não sou desses literatos que levam o leitor ao desatino. Escrevi uma novela - não publicaram. Escrevi um folhetim - recusaram. Esses folhetins eu levei a redações de várias revistas e de todas elas recebi um não: "É sal, dizem, o que lhe está faltando". ${ }^{4}$

Fica patente, portanto, o tratamento literário dentro da obra, de forma irônica. Dessa forma, Bakhtin (2010) argumenta que obras literárias que questionam as ideologias vigentes não são frutos exclusivos do século XVIII, o autor nos relata que essas narrativas ideológicas estão presentes desde o Helenismo, com as chamadas sátiras menipeias, narrativas produzidas pelo escritor Menipo e que visavam à visibilidade dos problemas sociais de sua cidade. Marcadas pelo riso e pela sátira, essas obras trouxeram à arena literária os primeiros rastros daquilo que se passou a visibilizar no romance: reprodução do

4 Dostoiévski, Fiódor. Bobók. Editora 34 Ebook Edição do Kindle. 
cotidiano de indivíduos sociais, representados por um sujeito mediano que podia se assemelhar a qualquer cidadão, provocando uma grande proximidade entre a personagem romanesca e o homem comum.

Essas narrativas, pautadas nas contradições do homem com o meio, passaram a ser chamadas gêneros sério-cômicos, que, centradas na experiência imediata, narravam cenas tristes por meio da gargalhada, indiciando consciência do instante verbalizado e da mundividência humana. Dessa forma, o contato direto com a sociedade em formação proporcionou o retrato carnavalizado nas imagens artísticas, e a ação, representada em momentos de enunciação, fora da distância épica, foi um dos principais elementos que diferenciou os gêneros elevados daqueles que se apropriaram da comicidade. Esse novo centro de narrar deu voz ao que o estudioso chamou de sátira menipeia, fazendo referência a Menipo de Gandara, pelo tom jocoso-crítico e o cinismo que o escritor grego representou em suas obras. Diante disso, Bobók é o conto considerado representante central desse gênero, pois carrega as várias características legadas a ele, como o dialogismo, a polifonia, o inacabamento, a polêmica velada, a inversão de espaços, a fantasia, entre outras diversas categorias literárias que fazem parte do estudo de Bakhtin acerca das obras do escritor russo.

\section{Bobók e a crítica ideológica}

Admirar-se de tudo é, sem dúvida, uma tolice, não se admirar de nada é bem mais bonito e, por algum motivo, reconhecido como bom-tom. Mas é pouco provável que no fundo seja assim. Acho que não se admirar de

nada é uma tolice bem maior do que admirar-se de tudo. Além do mais, não se admirar de nada é quase o mesmo que não respeitar nada. Aliás, um homem tolo não pode mesmo respeitar.

Dostoiévski 
O enredo de Bobók, conto narrado em primeira pessoa, mas que oferta a suas personagens a voz na descrição de seus pensamentos, descreve a história de Ivan Ivanovitch, escritor frustrado que, certo dia, sai à rua para se distrair e acaba indo parar em um cemitério. Após elocubrações, acaba entrando em estado de sonolência e começa a ouvir os mortos conversando. Perante o inusitado fato, silencia para ouvir a conversa. Esse estado inicial, que prepara o leitor para o fantástico: mortos conversando, gera o suspense na narrativa, que logo cederá espaço ao riso, uma vez que revela as fragilidades do homem em sociedade e sua posição ridícula perante o outro. Bakhtin salienta que:

O pequeno conto Bobók - um dos enredos de conto mais breve de Dostoiévski - é quase um microcosmo de toda a sua obra. Muitas ideias, temas e imagens de sua obra, todos sumamente importantes, manifestam-se aqui em forma extremamente arguta e clara: a ideia de que não existindo Deus e a imortalidade da alma "tudo é permitido" (um dos principais modelos de ideia em toda a sua obra). ${ }^{5}$

Dostoiévski cria uma arena de debate a partir da metáfora do cemitério: esse cemitério seria o local de escritores que já perderam espaço dentro do campo literário. Assim, o narrador romanesco cede voz a seus personagens para se autorrepresentarem: não fala por elas, cede a fala, em um movimento dialógico, em que o discurso do outro não encerra a discussão, apenas sinaliza para o surgimento de novas vozes sociais. Portanto, o discurso é sarcástico e irônico, revelando o ponto de vista narrativo apenas ao final da obra. Logo, carregado de observações éticas, filosóficas e históricas bem pontuais, com a finalidade de atingir cada um de seus críticos, o conto narra o enquadramento social, as ideologias, a necessidade de se inserir nos grupos por meio da bajulação, levando a narrativa a se assemelhar à obra Diálogo dos mortos, de Luciano, que apresenta como grandes personagens Menipo e Diógenes, dois filósofos gregos que criticavam autores mortos, assim como fizeram com o escritor do conto Bobók.

5 Bakhtin 2010, p. 165. 
O título da obra, segundo Paulo Bezerra, em sua tradução coloquial, significa "pequeno feijão". Assim, a crítica começa pelo título, pois, no ato da leitura, o leitor reconhecerá que essa referência é destinada às pessoas consideradas da classe média alta. Enquanto mantenedores dos dispositivos de discurso, as classes mais abastadas sentem-se superiores aos mais pobres, por sua vez, no reino dos mortos as vozes se equalizam, evidenciando que todos são iguais perante a morte. Diante disso, a ideologia de superioridade do reino dos vivos é rechaçada, os diálogos se sobrepõem, e o homem pode mostrar-se integral, dentro de suas fraquezas. Tal fato pode ser observado na seguinte citação:

E eu também lamento, só que para mim dá no mesmo e doravante quero desfrutar de tudo o que for possível. E não sou conde, mas barão, apenas barão. Nós somos uns baronetes sarnentos, descendentes de criados, aliás, eu até desconheço a razão disso e estou me lixando. Sou apenas um pulha da "pseudo-alta sociedade" e me considero um "amável polisson". Meu pai era um generalote qualquer e houve época em que minha mãe era recebida en haut lieu. ${ }^{6}$

Percebe-se que a personagem relembra a sua vida de barão, mas, rapidamente, destitui-se desse apetrecho, pois reconhece que, após a morte, ele não faz mais sentido. Assim, diminui a si e à sua linhagem, desprezando as classes sociais e suas chaves de poder. Tal cenário assemelha-se à praça pública, teoria criada por Mikhail Bakhtin, presente no livro A cultura popular na Idade Média e no Renascimento, em que o espaço unifica os indivíduos, logo a liberdade transcende o universo das classes, possibilitando o dialogismo e a interação entre identidades distintas. Nesses momentos, todos os atores da comunicação possuem direito a voz, apresentam suas ideologias sobre a vida, impossibilitando a presença de vozes hierárquicas que suprimem a comunicação.

Já dissemos que durante o carnaval nas praças públicas a abolição provisória das diferenças e barreiras hierárquicas entre as pessoas e a eliminação de certas regras e tabus vigentes na vida cotidiana criavam um tipo especial de comunicação ao mesmo tempo ideal e real entre as pessoas,

6 Dostoiévski, Fiódor. Bobók. Editora 34 Ebook. Edição do Kindle. 
impossível de estabelecer na vida ordinária. Era um contato familiar e sem restrições entre indivíduos que nenhuma distância separa mais. ${ }^{7}$

O cenário dialógico do conto discursa com as palavras do teórico russo, visto que abre espaço para a expressão das diversas ideologias, põe em palco os defeitos humanos, evidenciando que todos os indivíduos são padecedores de males sociais, independentemente do capital que os subsistem. Essa cena fica explícita quando os personagens do cemitério reconhecem o espaço de liberdade e se veem na condição de falar todas as usuras cometidas em vidas. Assim, traça-se um retrato crítico, as aparências são excomungadas, e o cidadão, integrante do carnaval que ocorre na praça pública, desvenda seu interior, coloca-se na posição de servo dos defeitos, o que resulta na equalização discursiva e social.

Na Terra é impossível viver e não mentir, pois vida e mentira são sinônimos; mas, com o intuito de rir, aqui não vamos mentir. Aos diabos, ora, pois o túmulo significa alguma coisa! Todos nós vamos contar em voz alta as nossas histórias já sem nos envergonharmos de nada. Serei o primeiro de todos a contar a minha história. Eu, sabei, sou dos sensuais. Lá em cima tudo isso estava preso por cordas podres. Abaixo as cordas, e vivamos esses dois meses na mais desavergonhada verdade! Tiremos a roupa, dispamo-nos! ${ }^{8}$

A alegria descreve a liberdade promovida pelo espaço dos mortos, ou mesmo, como fala Bakhtin, o espaço privado da vida, ressaltado no modo enunciativo da personagem. Diante disso, para o teórico russo, os signos são ideológicos. Portanto, até $o$ ato de pensar carrega ideologias, visto que se faz de discursos compostos por falas alheias, que são conjuntos de textos que expressam interação entre vozes para a composição de uma ideia. Essa pluralidade discursiva se articula ao que o autor denominou de polifonia, ou seja, o cruzamento das falas do cotidiano, o que desequilibra a unidade estável da cultura de um discurso pleno, com uma única verdade. Dedicando-se em especial às obras de Dostoiévski, o pensador observa nos

7 BAKHTIN, 2013, p. 14.

8 Dostoiévski, Fiódor. Bobók. Editora 34 Ebook. Edição do Kindle. 
romances desse escritor o choque entre os diversos vocabulários do cotidiano, o que impossibilita o aprisionamento da linguagem. Nesse viés, a linguagem popular, mais uma vez, ganha atenção, pois é a da maior parte da sociedade e representa sua particularidade cultural expressa na dialogia entre um eu e um outro, possibilitando abertura a outros tipos de consciências ideológicas e enunciados, como ocorre em Bobók, com as vozes em diálogo.

Dessa forma, a língua entra na questão identitária das diversas camadas sociais de um determinado povo. É comum surgir das camadas menos privilegiadas uma linguagem que expresse seus dilemas e particularidades. Tais elementos a distanciam da linguagem das camadas mais privilegiadas, criando um fosso entre classes que falam uma mesma língua. Mas Bakhtin, por sua vez, acreditava na força das classes populares em reagir contra a coisificação da linguagem, especialmente porque, para o teórico, a linguagem é um artefato social, e a língua vive em constante interação. Em vista disso, o pesquisador reconhecia a riqueza dessas formas linguísticas e dava a elas o tônus da liberdade. Os palavrões, nessa perspectiva, eram a capacidade de o falante se afastar das amarras da linguagem oficial - que surge aqui como algo opressivo - e deixar sua unicidade falar. Nesse viés, é importante perceber que a língua tanto serve de recurso de dominação como de libertação, como é o caso do estudo acerca da carnavalização literária, que possibilita ao homem a liberdade momentânea na linguagem.

No conto de Dostoévski, tal fato se explicita quando as personagens percebem a liberdade discursiva no território dos mortos e veem nesse espaço a liberdade para falarem de seus erros, pois percebem que ninguém será capaz de repreendê-los. Nesse ponto, o discurso narra a vida não oficial, a liberdade almejada, fora da exigência das aparências sociais, que fazem o homem viver sob a máscara, que reifica identidades, silencia grupos sociais. Nesse espaço, os corpos vivem em regime de proximidade, não há o afastamento proporcionado pelas classes sociais, que condenam o homem ao aprisionamento na vida. 
Em primeiro lugar, o espírito. Com uns quinze mortos fui logo dando de cara. Mortalhas de todos os preços; havia até dois carros funerários: o de um general e outro de alguma grã-fina. Muitas caras tristes, e também muita dor fingida, e muita alegria franca. O pároco não pode se queixar: são rendas. Mas espírito é espírito... Eu não queria ser o pároco daqui. ${ }^{9}$

A cena deixa clara a separação por classes, mas também a proximidade dessas classes após a morte, o que fez aflorar a diversidade de ideologias discursivas. Mas é necessário frisar que existem dois tipos de ideologias - oficial e do cotidiano - que são intercambiáveis, uma vez que a interação discursiva possibilita o entrelaçamento linguístico e ideológico, aproximando as variadas classes sociais: o hibridismo. No conto, relembra-se a ideologia oficial, a importância das personagens literárias no mundo dos vivos, mas a conclusão alcançada é a unificação que o mundo dos mortos sela. Assim, percebe-se a linguagem de igualdade, marcada pela oralidade ao desvendar os defeitos humanos. Dessa forma, o caráter cômico das sociedades estava mesclado à linguagem dos festejos e da descontração, portanto, a certa liberdade que aproximava momentaneamente os contrários, ao abrir caminhos para possíveis mudanças sociais. Mas Bakhtin (2013) não esquece uma de suas principais características: a ambivalência, pois ao mesmo tempo em que encena a alegria, se guarda também do deboche, da crítica, em especial da restauração/renovação das estruturas sociais. Em Bobók, percebemos a dupla articulação da linguagem, as possibilidades de sentidos que as palavras podem gerar nos corpos em contato, e assim surgem os princípios dos enunciados irônicos, a farsa da linguagem para representar pontos de vista diversos e inverter o pensamento dominante.

Mas, justamente porque a linguagem possui uma ambivalência ineliminável - fruto da contradição entre o real inesgotável, infinito, e a necessidade de dizê-lo adequadamente em termos finitos -, as palavras utilizadas por todos acolhem não só a marca dos critérios impostos pelos opressores como também, algumas vezes, a marca da resistência dos oprimidos. ${ }^{10}$

9 Dostoiévski, Fiódor. Bobók. Editora 34 Ebook. Edição do Kindle.

10 (KONDER, 2002, p. 153) 
Com esse retrato do inacabamento do homem, o conto aproxima as pessoas, coloca-as como padecedoras de defeitos, humaniza o sujeito, reafirmando suas fragilidades perante a vida e seu pertencimento à unidade instável da cultura. A unidade fundamental da linguagem é o diálogo com o outro, segundo Bakhtin. A comunicação, como processo limiar de interação entre duas identidades distintas, se revela na compreensão responsiva dos enunciados. Embora o autoritarismo se afeiçoe do monologismo como força de opressão e manutenção de poder - especialmente nas tentativas das personagens em manter a posição que carregavam no mundo dos vivos -, os diálogos promovidos no conto pressupõem a voz do outro, possibilitam a réplica enunciativa e mantêm a natureza dialógica da linguagem, natureza essa que possibilita a troca e favorece a ironia como uma figura retórica que, geralmente, espera uma reação do interlocutor, requer o diálogo, a troca, a respondibilidade.

Perversão em um lugar como este, perversão das últimas esperanças, perversão de cadáveres flácidos e em decomposição, sem poupar sequer os últimos lampejos de consciência! Deram-lhes, presentearam-nos com esses lampejos e... E o mais grave, o mais grave: num lugar como este! Não, isto eu não posso admitir..."

Diante do exposto, percebe-se que a dessacralização do corpo é a dessacralização do homem, em que o discurso enunciativo contribui para a decomposição das figuras sociais, em gesto responsivo e ideológico. Para Beth Brait, o processo dialógico é essencial na constituição da respondibilidade narrativa, posto que:

Necessariamente, aceitando-se que texto e discurso são processos que implicam produção e recepção, ou seja, sujeitos envolvidos em uma interação, a perspectiva interessa-se também pelo destinatário que, assim como seu parceiro, detém diferentes papéis, aparecendo como receptor, interlocutor, ouvinte, enunciatário, leitor, e cuja função ativa no discurso será participar da dimensão significativa, na medida em que é o ponto visado pelas estratégias elaboradas pelo produtor. $\mathrm{O}$ conceito de efeito de sentido parece pertinente

11 Dostoiévski, Fiódor. Bobók. Editora 34 Ebook. Edição do Kindle. 
na articulação produção-recepção envolvida por um texto, por um conjunto de textos que podem configurar um discurso, ou mesmo pelo discurso entendido como manifestação da linguagem em funcionamento. ${ }^{12}$

Assim, ao parodiar as imagens autoritárias, o autor traz para a obra a ironia ao sistema de sociedade presente no país; os recursos estéticos utilizados são os graus da orientação dialógica, ou seja, os tons empregados pelo enunciador para descrever o discurso de seus personagens e aproximá-los das falas do cotidiano. Nesse sentido, a literatura surge como a voz de uma ideologia, posto que ela deve ser vista como o retrato de seu tempo, pois "nasce sempre frente a uma realidade histórica e, frequentemente, contra essa realidade". ${ }^{13}$ Portanto, diante desses embates que se repetem ao longo da história, a arte é essencial para a equalização discursiva, tendo em vista que expressa a pluralidade de linguagens da vida.

\section{A síntese}

Bakhtin, em Questões de literatura e de estética (2014), discute a relação inalienável entre o objeto artístico e a vida cultural. Para o autor, quando se renega a arte, é como se estivéssemos definindo-a. Esse processo adquire forma a partir do momento em que o pensamento axiológico de determinada sociedade está entrelaçado ao ato estético-cultural de seu tempo. Não por acaso, os artifícios moldados pelo produtor de arte estão formalizados pelos artefatos culturais e os modos de pensar de seu tempo, ou seja, a cultura de pensamento de sua comunidade. Quando recorremos ao sentido de ideologia, estamos diretamente articulando os sentidos éticos produzidos na vida com os elementos estéticos desse cronotopo. "De fato a vida não se encontra só fora da arte, mas também nela, no seu interior, em toda plenitude de seu peso axiológico: social, político, cognitivo ou outro que seja. A arte é rica, ela não

12 Beth Brait, 2008, p. 15.

13 Paz, 1972, p. 126. 
é seca nem especializada." (BAKHTIN, 2014, p. 33) A obra de arte, portanto, aproxima homem e natureza, denomina-os em suas condições de pré-existência, unificando a beleza da natureza com a humanização do homem-animal. Esse processo faz a arte, na livre percepção de seu criador, evocar a liberdade como elemento constituinte, procedendo ao relato a partir de sua construção enquanto sujeito histórico portador de determinada ideologia. Nessa mesma linha de pensamento é que Bakhtin, a respeito da autonomia da arte, afirma que ela:

é baseada e garantida pela sua participação na unidade da cultura, tanto que a definição sistemática ocupa aqui um lugar não só singular, mas também indispensável e insubstituível; caso contrário essa autonomia seria simplesmente arbitrária. ${ }^{14}$

Diante disso, a arte não aprisionada a um sistema de valores faz transparecer a unicidade do pensamento de uma época, seja na sua posição crítica, seja no engrandecimento da forma de pensamento de determinado período. Em linhas gerais, Bakhtin nos ensina que é a partir do momento que o escritor transforma as coisas à sua volta em sentido, por meio do tom empregado, que a palavra se faz discurso e pode influenciar pontos de vistas. Nesse sentido, é a tomada de conhecimento, o ato responsável, que aproxima o leitor e proporciona a compreensão responsiva, a resposta criativa à obra literária. O leitor, enquanto depositário ativo das informações entrelaçadas ao tecido literário, ao ler cada rabisco que compõe a escritura, vai criando sua cadeia de pensamento própria; e o escritor não é mais que esse leitor, um reelaborador de informações que une os variados atos do cotidiano e vai criando seu horizonte de expectativas, vai tecendo sua imagem de mundo em palavras, que são escudeiras de ideologias, e ritualizam, por meio da ambivalência literária, os percursos formativos da vivência humana. A depender do leitor, essa experiência de leitura possibilita diversificadas possibilidades, pois, de acordo com Bakhtin (2011, p. 27):

Às vezes, quando as pessoas sem cultura leem sem arte um romance, a percepção artística é substituída pelo sonho,

14 Bakhtin, 2014, p. 16. 
não por um sonho livre e sim predeterminado pelo romance, um sonho passivo, e o leitor se compenetra da personagem central, abstrai-se de todos os elementos que lhe dão acabamento, antes de tudo da imagem externa, e vivencia a vida dessa personagem como se ele mesmo fosse o herói dessa história.

O conto de Dostoiévski, portanto, surge como objeto literário catalizador de ideologias, portanto, influenciador de pontos de vistas. Em Bobók, as falas literárias confrontam o leitor com enunciados que lhe reservam o riso, posto o papel ridículo do enunciador. Quando as personagens estão em estado de liberdade, ou seja, no ambiente particular, resguardadas da praça pública, os pensamentos perversos veem à tona, e podemos, assim, reconhecer seus defeitos, unificá-los enquanto humanidade, padecedora de erros, coberta por defeitos, aproximando, nesse sentido, as classes sociais. Esse conteúdo literário, em vista disso, convida o leitor a perscrutar sua unicidade, por meio do relato cômico, visando ao reconhecimento de si e do outro e de seus papéis ideológicos formativos de corpo social.

Dessa forma, retrata-se a importância dessa obra literária para a visão de mundo da sociedade russa em tempos de escritura de Dostoiévski, que apresenta ao leitor tanto conteúdo estético primoroso quanto conteúdo histórico. Mas não apenas isso, o conto se mantém atual, contribuindo fortemente para a leitura de mundo do leitor moderno.

\section{Referências bibliográficas}

BAKHTIN, Mikhail. A cultura popular na idade média e no renascimento - o contexto de François Rabelais. Tradução de Yara Frateschi Vieira. 8. ed. Brasília: Editora Universidade de Brasília, 2008.

BAKHTIN, Mikhail. Questões de Literatura e de Estética: a teoria do romance. Tradução de Aurora Fornoni Bernardini. 7. ed. São Paulo: Hucitec, 2014.

BAKHTIN, Mikhail. Problemas da poética de Dostoiévski. Tra- 
dução de Paulo Bezerra. 6. ed. Rio de Janeiro: Forense Universitária, 2010.

BRAIT, Beth. Ironia em perspectiva polifônica. Campinas: Editora Unicamp, 2008.

BEZERRA, Paulo. "Prefácio: uma obra fora do tempo". In: BAKHTIN, Mikhail. Problemas da poética de Dostoiévski. Tradução de Paulo Bezerra. 6. ed. Rio de Janeiro: Forense Universitária, 2010.

DOSTOIÉVSKI, Fiódor. Bobók. Editora 34. Ebook. Edição do Kindle.

FIORIN, José Luís. Linguagem e ideologia. São Paulo: Ática, 2007.

KONDER, Leandro. A questão da ideologia. São Paulo: Companhia das Letras, 2002.

LYRA, Pedro. Literatura e ideologia. Petrópolis: Editora Vozes, 1979.

PAZ, Octávio. Signos em rotação. Tradução de Sebastião Uchoa Leite. São Paulo: Perspectiva, 1972.

Recebido em: 15/10/2021

Aceito em: 30/11/2021 